\title{
Comparison of antidepressant effect of Melissa officinalis L. hydroalcoholic extract with fluoxetine in male mice
}

\author{
Shadi Hajrasouliha ${ }^{1,2}$, Shahrzad Khakpour ${ }^{3}$ \\ ${ }^{1}$ Department of Biology, Herbal pharmacology Research Center, Tehran Medical Sciences, Islamic Azad University, \\ Tehran, Iran \\ ${ }^{2}$ Department of Biology, Roudehen Branch, Islamic Azad University, Roudehen, Iran \\ ${ }^{3}$ Department of Physioloy, Herbal Pharmacology research center, Tehran Medical Sciences, Islamic Azad University, \\ Tehran, Iran
}

\begin{abstract}
Background: Depression is a common psychological disorder and recent data confirm the increasing prevalence of this disease in the world. So far, antidepressant effects of many plants have been evaluated and some are accepted in the treatment of depression. The aim of the present study was to determine the antidepressant effect of Melissa Officinalis L. compared to fluoxetine.

Materials and methods: In the present study, the antidepressant effect of Melissa officinalis L. was studied and compared with fluoxetine in experimental groups of mice using FST (Forced Swimming Test), TST (Tail Suspension Test). Melissa officinalis L. extract with different doses of 600,800, and $1000 \mathrm{mg} / \mathrm{kg}$ was prescribed by gavage for 7 days. One way ANOVA was used to analyze data by SPSS software.

Results: Among the different doses, $600 \mathrm{mg} / \mathrm{kg}$ Melissa officinalis L. extract and fluoxetine had the same effect in the reduction of depression.

Conclusion: The antidepressant effect of Melissa officinalis L. extract is probably induced by the variation of monoamines release in central nervous system.

Keywords: Melissa officinalis, Depression, Mice, Fluoxetine.

Cited as: Hajrasouliha Sh, Khakpour Sh. Comparison of antidepressant effect of Melissa officinalis L. hydroalcoholic extract with Fluoxetine in male mice. Medical Science Journal of Islamic Azad University, Tehran Medical Branch 2020; 30(4): 418-424.

Correspondence to: Shahrzad Khakpour

Tel: +98 22006660-021

E-mail: shahrzad_khakpour@yahoo.com

ORCID ID: 0000-0003-1782-3989

Received: 15 Oct 2019; Accepted: 15 Feb 2020
\end{abstract}


مجله علوم يزشكى دانشكاه آزاد اسلامى

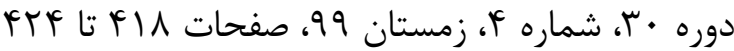

مقايسه اثر ضد افسردگى عصاره هيدروالكلى گياه بادرنجبويه با فلوكستين درموش سورى نر (Melissa officinalis L.)

شادى حاج رسوليها '، شهرزاد خاكيور

' ' كروه زيست شناسى، مركز تحقيقات فارماكولوزى كياهان دارويى، علوم يزشكى تهران ، دانشكاه آزاد اسلامى تهران، ايران

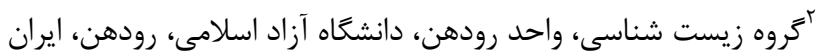

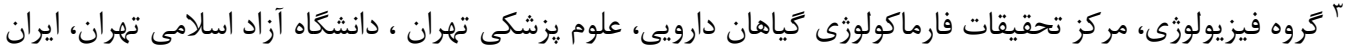

جكيده

سابقه و هدف: افسردىى يكى از شايعترين اختلالات روان بزشكى /ست و يافتهاى جدائ جديد مويد افزايش شيوع /ين بيمارى /ست.

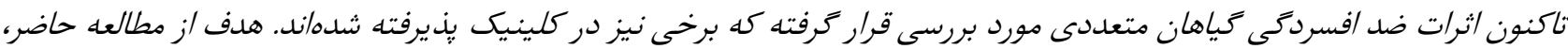

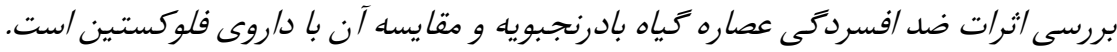
روش بررسى: اثر ضد افسردىى كياه بادرنجبويه با داروى فلوكستين /ز طريق تست شناى اجبارى (Forced Swimming Test .FST) و تست دارت

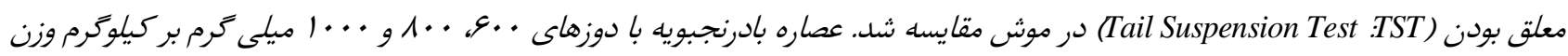

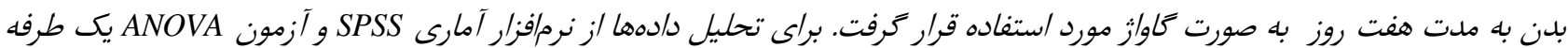
استفاده شد.

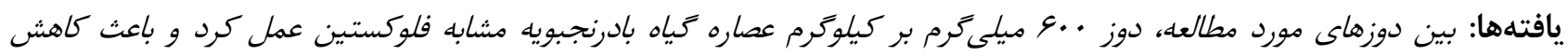
| (فسردكى شد. نتيجه כيرى: با توجه به يافتهاى /ين مطالعه كه عصاره كياه بادرنجبويه همانند فلوكستين داراى اثر ضد /فسردىى است، مىتوان نتيجه

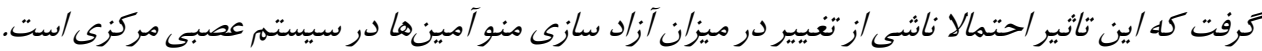
وازگًان كليدى: بادرنجبويه، افسردىى، موش، فلوكستين.

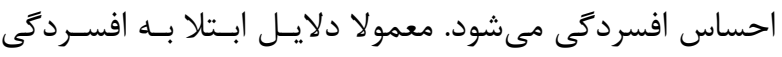
مقدمه

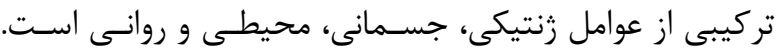

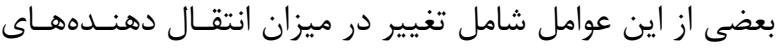

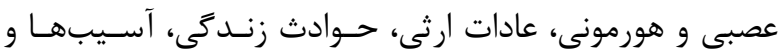

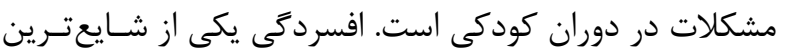

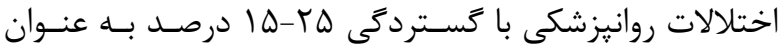
يكى از مهمترين معضلات قرن معاصر شناخته شده است (T).

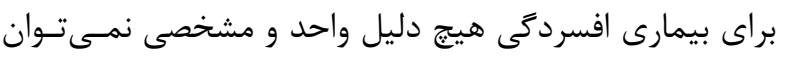

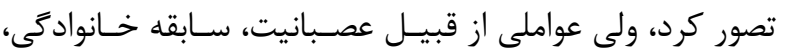
وابستخى به الكل و مواد مخدر، شكست در كار، ازدواج يا روابط ليط

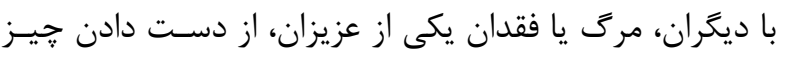
افسردكى، بيمارى روحى روانى است كه باعث احســاس غـمه و ناراحتى مداوم و از دست دادن علاقه در افراد مسىشـود. البتـهـ

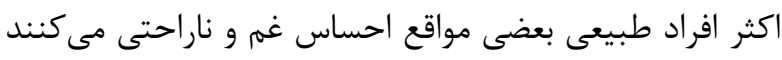

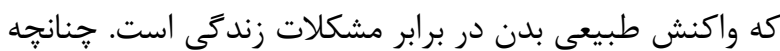
احساس غم و ناراحتى براى طولانى مدت ادامه بِيدا كند، باعت بـات

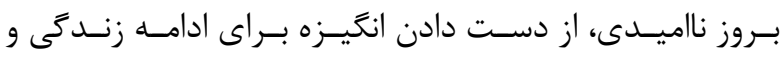

آدرس نويسنده مسئول: تهران، مركز تحقيقات فارماكولوزى گياهان دارويس، دانشعاه علـوم يزشكى آزاد

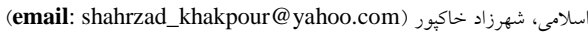
rq৯q-IVAr_...r_.... ORCID ID 


\section{مواد و روشها}

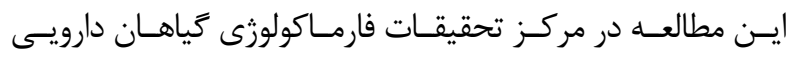

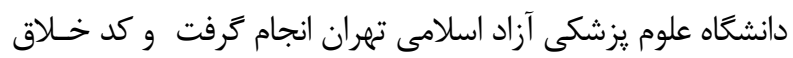
آن IR.IAU.TMU.REC.1395.191 است.

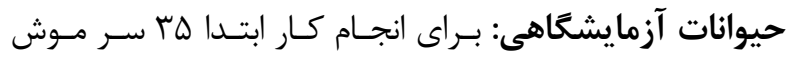

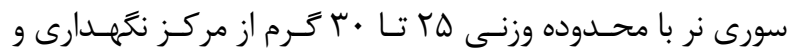

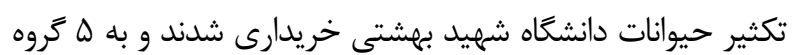

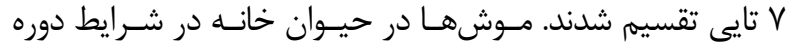

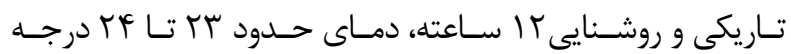

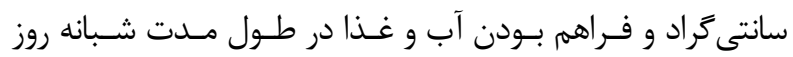
ن نكهدارى شدند. آماده سازى عصاره كياهى: براى تهيه عصـاره كيـاهى، از روش

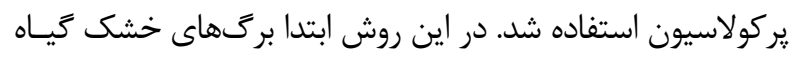

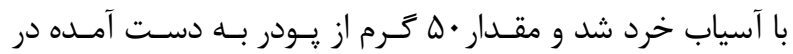

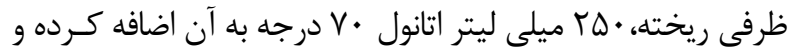

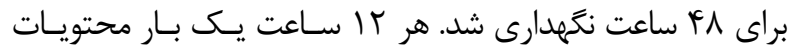

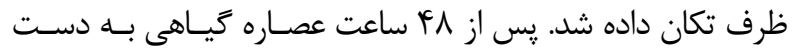

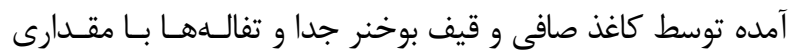

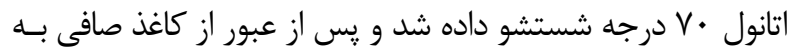

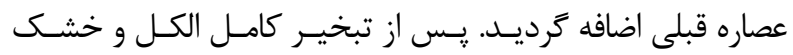

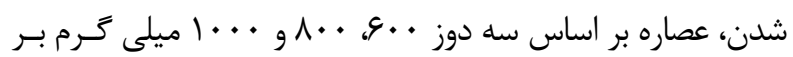
كيلوكرم توزين و در سرم فيزيولوزى حل شد.

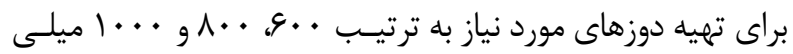

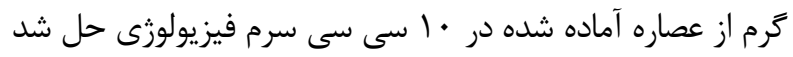

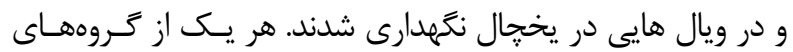

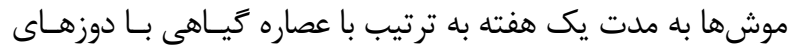

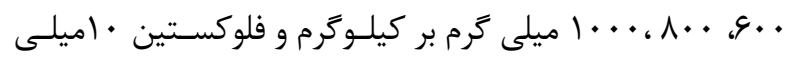
كرم بر كيلوكرم وزن بدن تحت تجويز از طريق كاواز قـرار كرفتيتـد

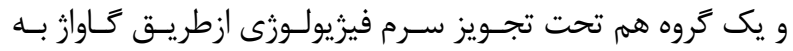

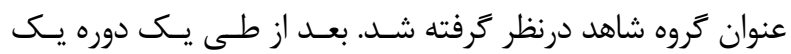

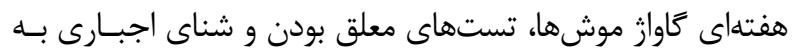

طور جداگانه روى تك تك حيوانات آزمايشكاهى انجام كرفت.

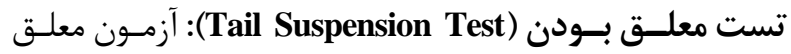

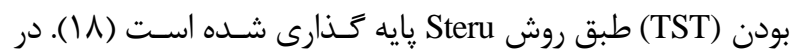

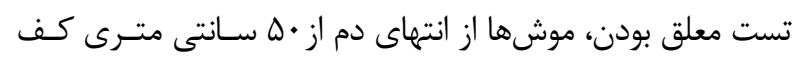

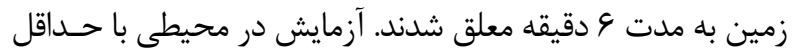

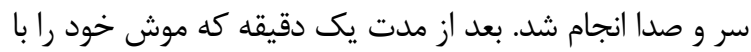

مهمى مانند شغل، خانه و يا سرمايه، تغيير شغل، نقـل مكــان،

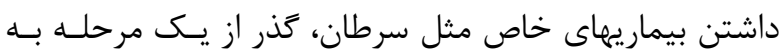

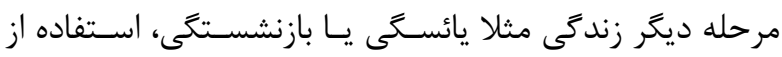

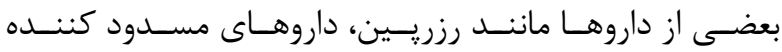

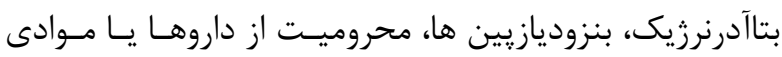

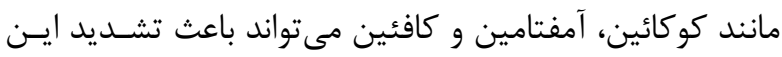

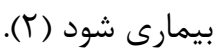

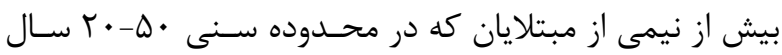

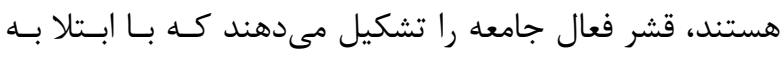

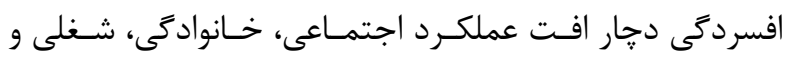
فشارهاى روانى و عاطفى شديد مسىشـوند. دو سـوم مبتلايـان

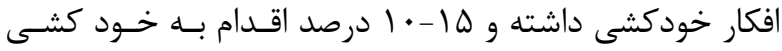

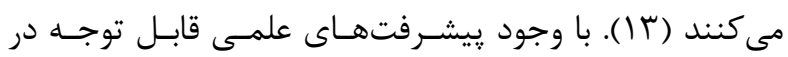
توليد داروهاى جديد هنوز بسيارى از بيماران دجار افسـردىى

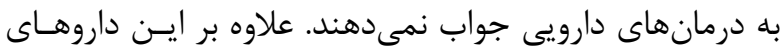

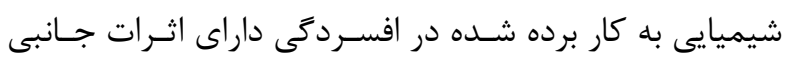

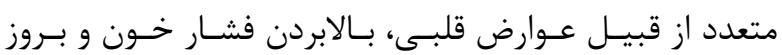

اختلالات جنسى هستند (1).

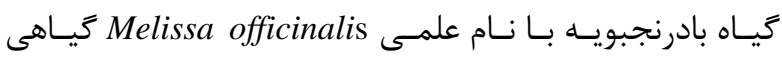

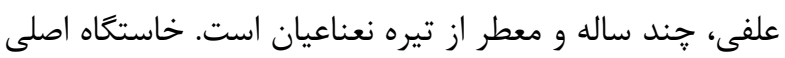
آن شرق مديترانه است، ولى در بعضى از نقــاط آذربايجـان و

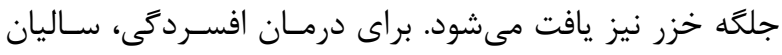

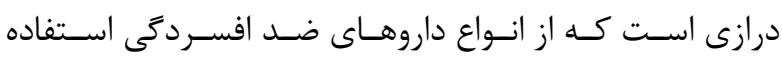

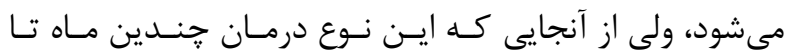

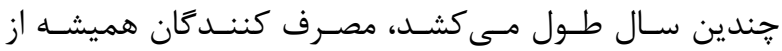

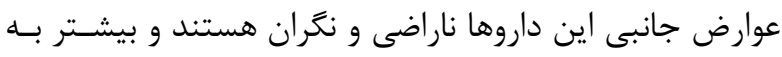

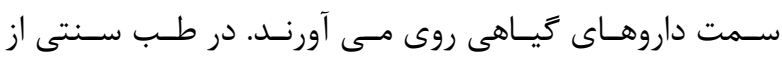

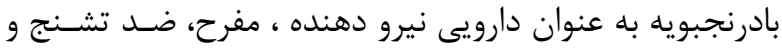

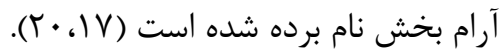

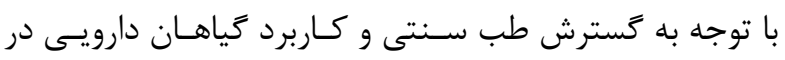

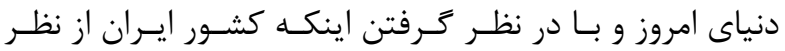
يوشش كياهى بسيار غنى است و كونـهـهـاى مختلـف كياهـان

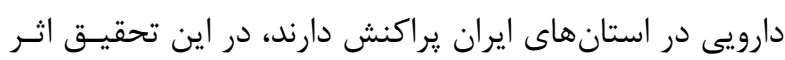

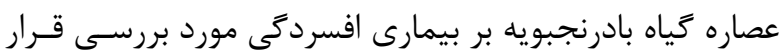

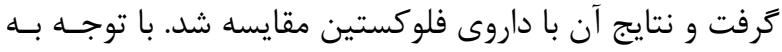

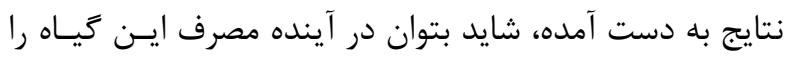

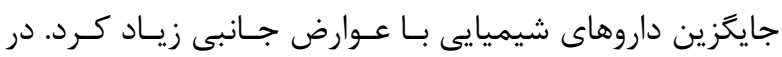
تحقيق حاضر، اثر ضد افسردىى كياه بادرنجبويه با اسـتفاده از تست شناى اجبارى و تست معلق بـودن در مـوش سـورى نـر

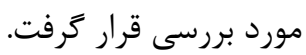


ميلى

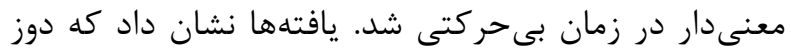

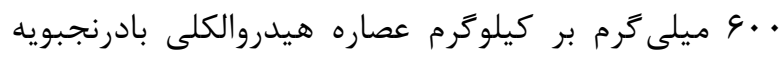
همانند داروى فلوكستين در كاهش بى حركتى در آزمون برد معلق بودن نقش دارد.

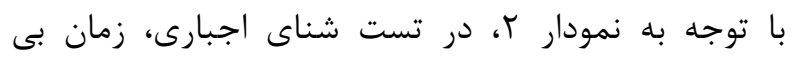

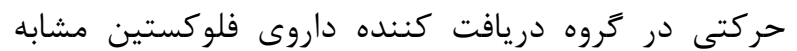

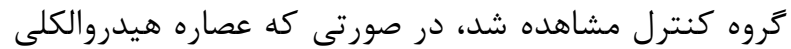

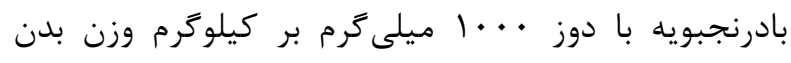

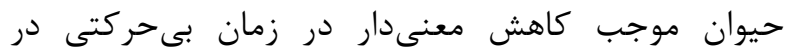

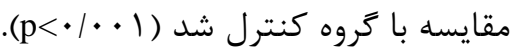

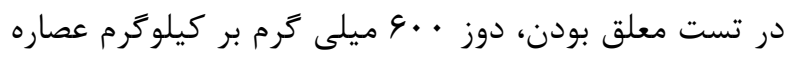
هيدروالكلى كياه بادرنجبويه مشابه فلوكستين • •ا ميلى گَرم بر كيلوگرم در مقايسه با گروه كنترل زمان بى حركتى

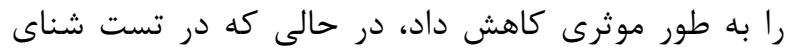

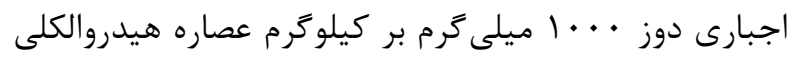

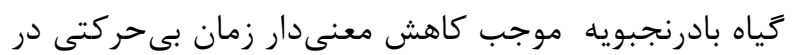

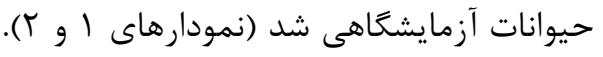

\section{بحث}

در تحقيق حاضر، اثر ضد افسردىى گياه بادرنجبويه با استفاده از تست شناى اجبارى و تست معلق بودن در موش سورى نر مورد بررسى و مقايسه با داروى فلوكستين قرار خرفت. با توجه به نتايج حاصل از اين مطالعه، عصاره هيدروالكلى كياه
شرايط تطبيق داد، به مدت بنج دقيقه زمانهاى بى حركت بـودن كامل كه نشانه افسردگى است ثبت شد. تست شناى اجبارى Forced Swimming Test): از متداولترين تستهاى بررسى افسردگى در حيوانات است (ها،

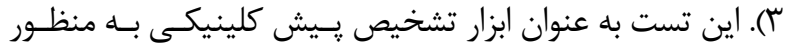
ارزيابى اثر ضد افسردىى داروهاى جديد بسيار مورد اسـتفاده قـرار

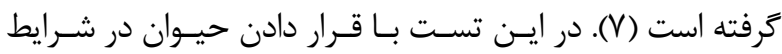
استرس با مكانيسم احتمالى تضعيف سيستم ايمنى موجب شـبيه

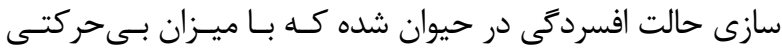
سنجيده مىشود (Y)، r).

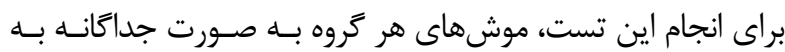

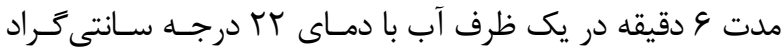

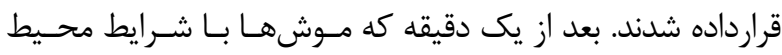

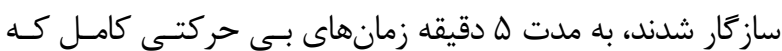
نشانه افسردگى بود، ثبت شد. تمامى دادهها به صـورت ميـانگين \pm انحـراف معيـار بيـان

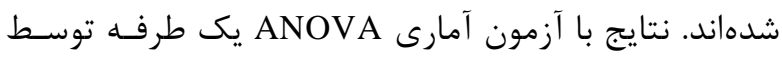

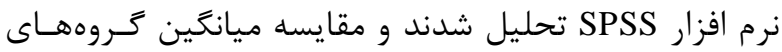

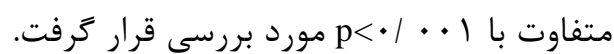

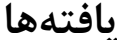

با توجه به نمودار ا، در تست معلق بودن، داروى فلوكستين

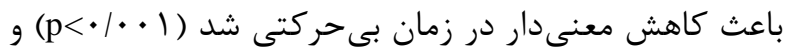

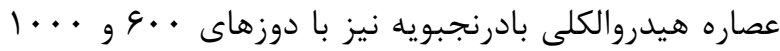

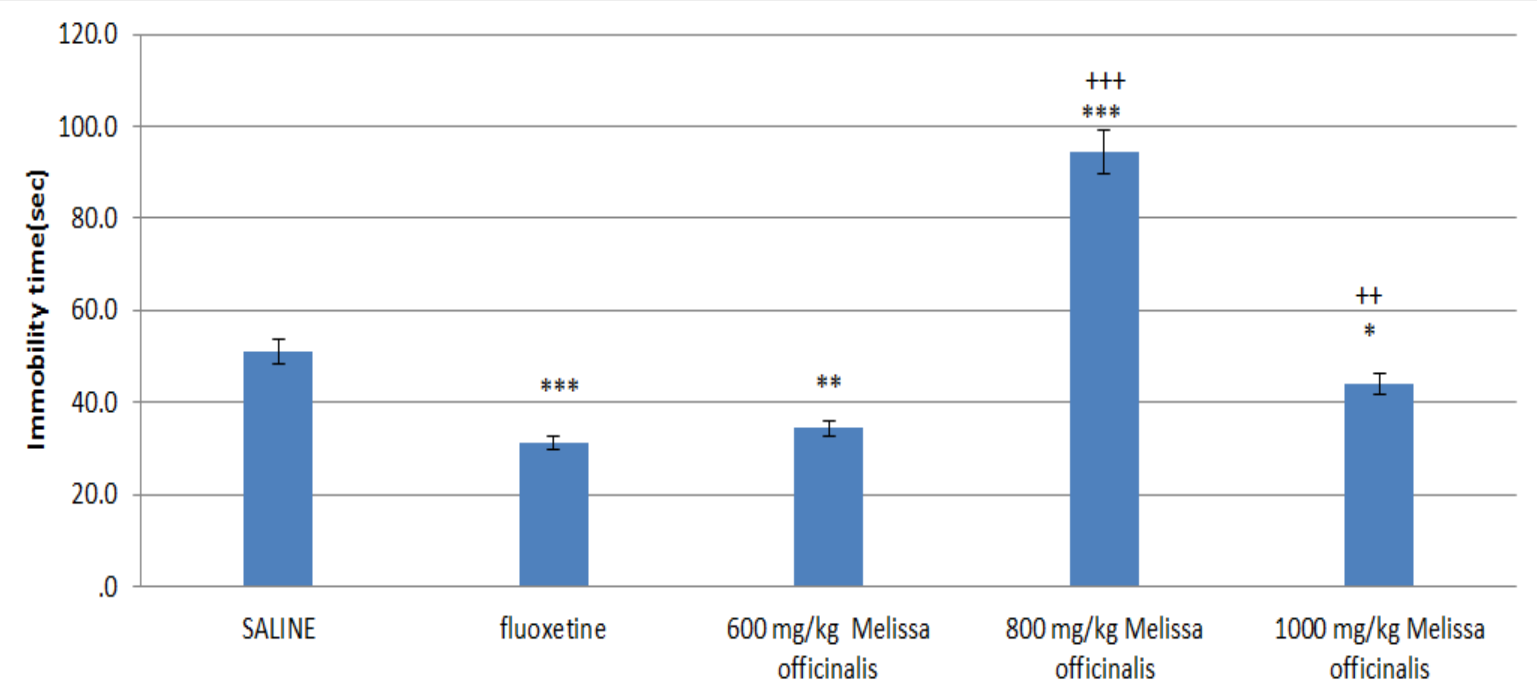

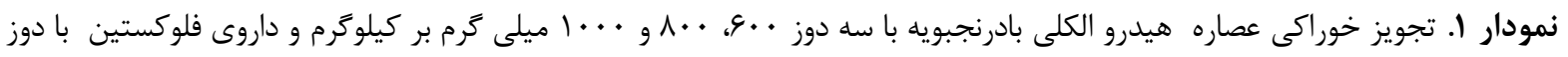

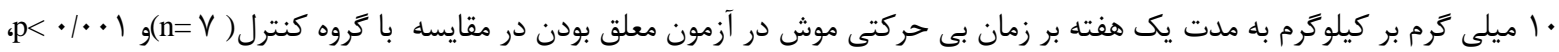




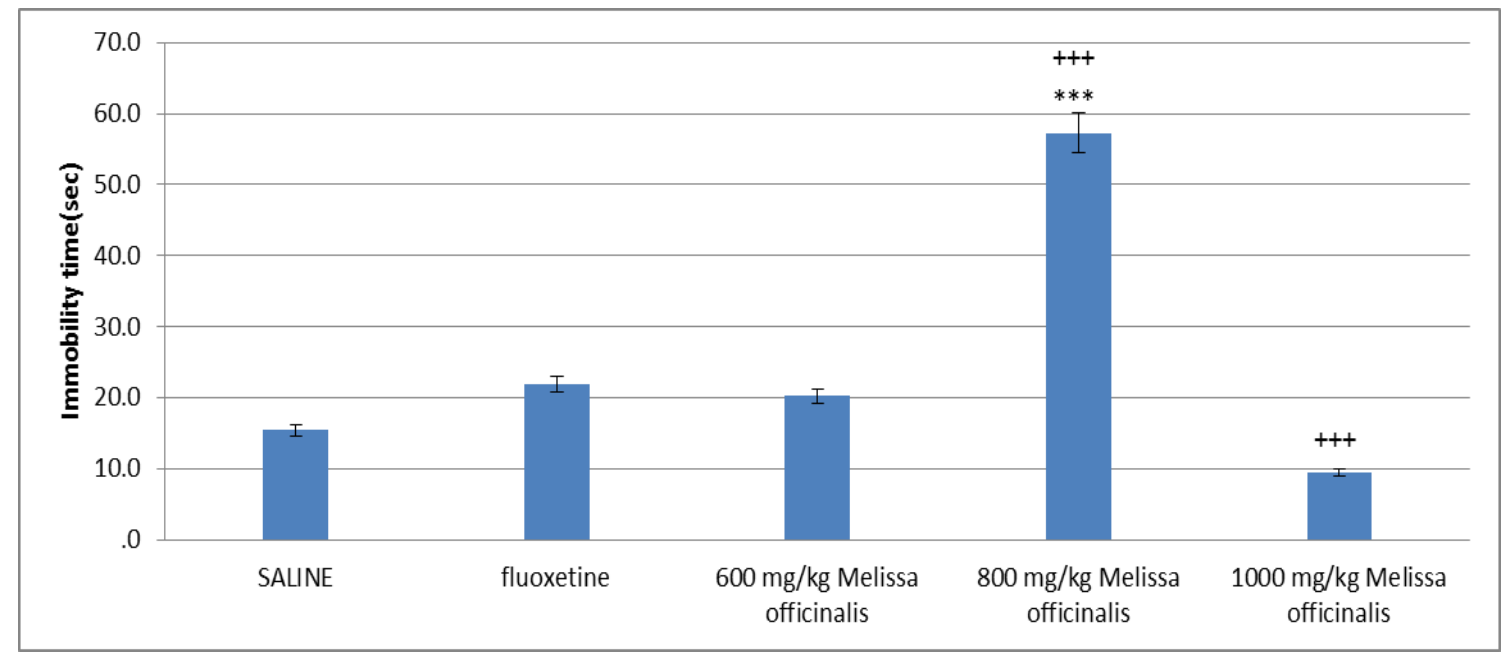

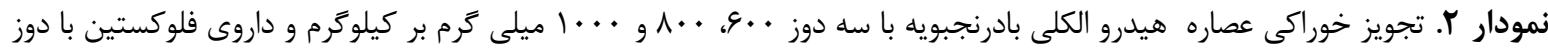

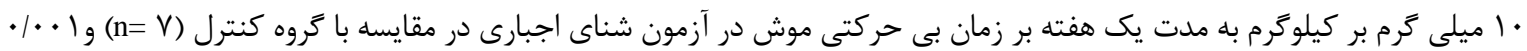
F(4,30)=94.4 p<0.001، Forced Swimming Test ، p<

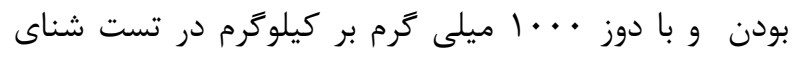

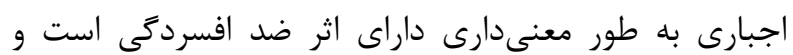
مشايه با داروى فلوكستين عمل مى كند.

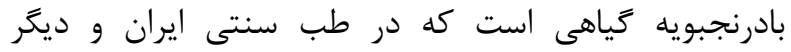

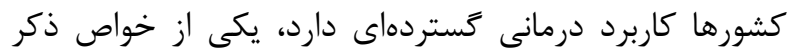
شده براى اين كياه خاصيت آرام بخشى و ضد تشنجى آن دآن

غيور و همكاران در سال •وץ"ا، در بررسىهاى خود اعلام كردند كه عصاره آبى الكلى گياه بادرنجبويه داراى اثرات آرآ بخشى و ضد تشنجى است و احتمالا از طريق سيستم كابائرزيك اثرات خود را اعمال مى كند (9).

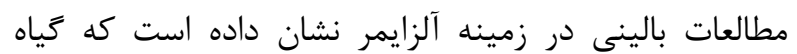
بادرنجبويه بر روى رسيتورهاى استيل كولين تاثير مى كذارد و

موجب افزايش توانيى شناخت در افراد مىشود (1)، If).

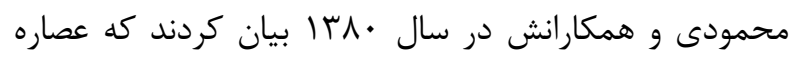
كياه بادرنجبويه در يِيشكيرى از ظهور علايم تشنج ناشى از

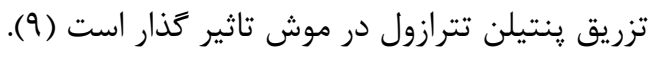

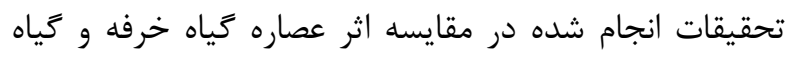
بادرنجبويه بر تعديل دوره خواب حاكى از آن است كه عصاره

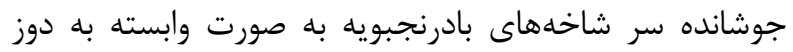

موجب افزايش دوره خواب مىشود (· •(1).

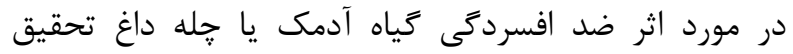
مشابهى انجام شده كه نتايج به دست آمده با نتايج تحقيق حاضر تا حدود زيادى هميوشانى دارد (b).
بادرنجبويه (Melissa officinalis L.) خواص ضد افسردىى دارد. در جامعه امروزى، افسردگى بيمارى بسيار جدى به به

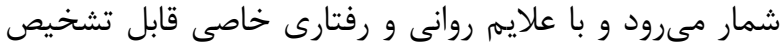

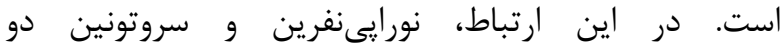

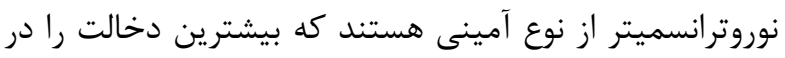

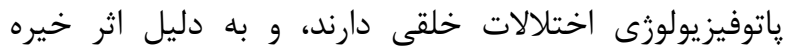
كنندهاى كه مهار بازجذب سروتونين در درمان افسردكى دارد،

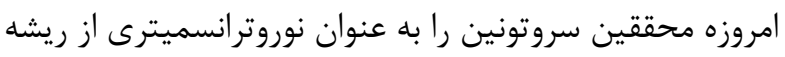
آمينهاى زيستى مىشناسند كه بيشترين ارتباط را با بيمارى افسردگى دارد. فلوكستين داروى سه حلقهاى مهار مهار كننده انتخابى باز جذب سروتونين يا Selective Serotonin) Reuptake Inhibitor) SSRI متداول در درمان بيمارى افسردگى است (؟).

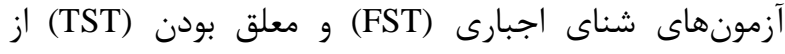

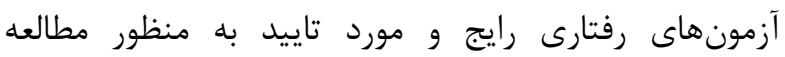
اثربخشى بالينى داروهايى با اثرات ضدافسردگى در حيواني

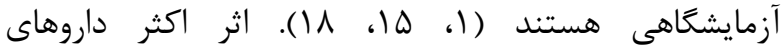

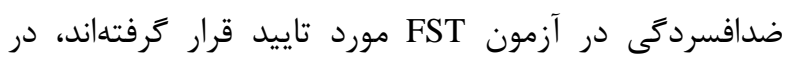
صورتى كه داروهاى با اثرات آرام بخشى و نوروليتيكها، اثرات

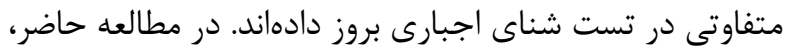

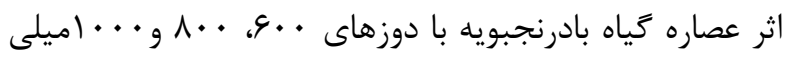

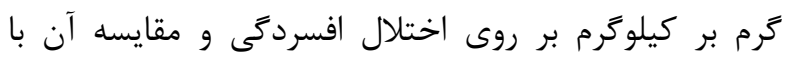
مصرف داروى شيميايى فلوكستين مورد بررسى قرار ترفتي.

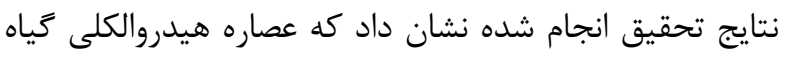
بادرنجبويه در دوز .9 ميلى كرم بر كيلوكرم درتست معلق 
حساسيت گيرندهها (receptor sensitivity) ) نسبت به عصاره به شدت كاهش ييدا كرده و عدم بروز زياسخ محسوس را مى-

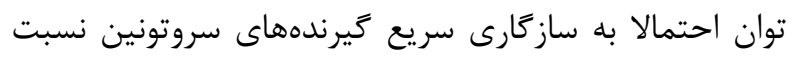

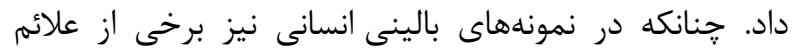
افسردگى را ناشى از سازگًارى گيرندهاى سروتونين نسبت به به به

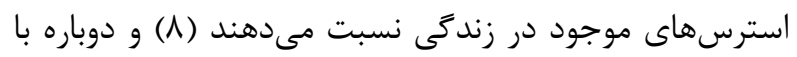

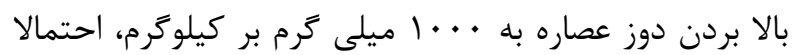

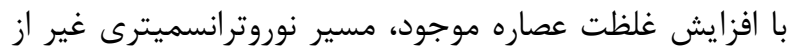

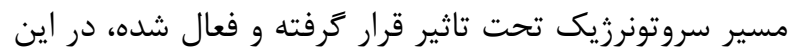
ارتباط بيشتر به فعال شدن مسير كابائرزيك احتمال داده

$$
\text { مى شود. }
$$

به طور كلى مطالعات مختلف نشان دادهاند كه عمده علايم

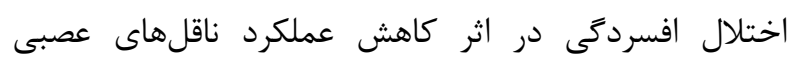
منوآمين شامل سروتونين، نورايى نفرين و دويامين در مغز ايجاد مىشود و داروهاى ضد افسردگى رايج قادرند با افزايش لوني

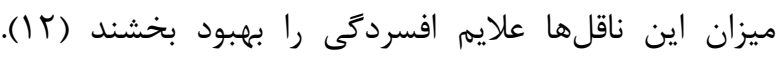
احتمالا عصاره هيدروالكلى زياه بادرنجبويه با مكانيسم مهار بازجذب سروتونين اثر ضد افسردىى خود را به جا مى گذارد. با توجه به نتايج بدست آمده و مطالب ذكر شده، احتمالا

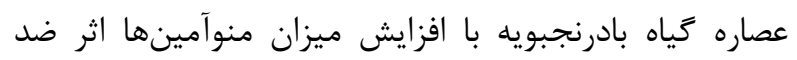
افسردگى دارد. البته، ذكر مكانيسمهاى تاثير عصاره گياه بادرنجبويه نياز به مطالعات و تحقيقات بيشترى دارد. همجنين بايد در تمامى آزمونهاى تجربى بالينى در نظر داشت كه ده تاثير

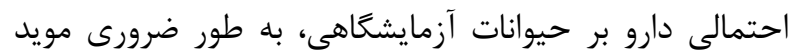
موثر بودن آن در انسان نيست. لذا بررسى اثرات ضدافسردكى

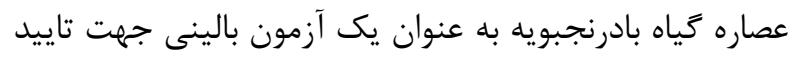

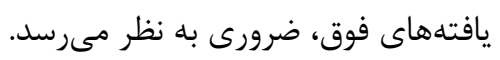

\section{تقدير و تشكر}

اين مطالعه با استفاده از اعتبار يزوهشى مركز تحقيقات

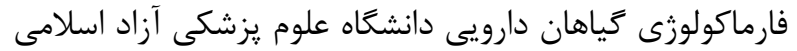
تهران به انجام رسيده است و بدين وسيله از معاونت يزوهشى و فن آورى دانشعاه علوم يزشكى آزاد اسلامى تهران به جهرت

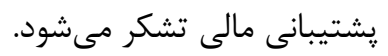

به طور كلى داروهاى با اثر ضدافسردگى را مىتوان از داروهاى محرك كاملا تميز داد، زيرا داروهاى محرك، تحريك محسوس بـ بـ

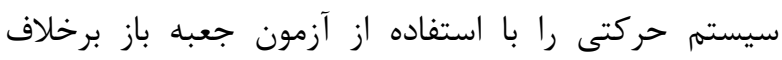
داروهاى ضدافسردگى باعث مىشوند (9 (1). به عبارتى ديخر، داروهاى محرك با داروهاى ضد افسردگى كاملا متفاوت هستند، جرا كه داروهاى محرى بر بر خلاف داروهاى ضد ضد افسردگى موجب تحريك عملكرد حركتى مىشوند (19).

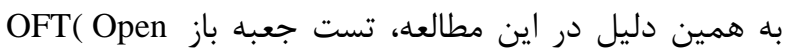
در زروههاى تجربى جهت : Field Test) حركتى حيوانات صورت گرفت و مشاهده شد كه عصاره زياه

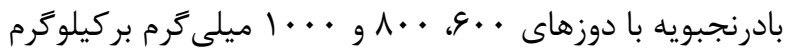
و همجنين داروى ضد افسردگى فلوكستين تفاوت معنىدارى را در عملكرد حركت حيوانات ايجاد نكردند. به طور كلى در علم فارماكولوزى، داروهاى ضد افسردگى به عنوان تغييردهنده ميزان برخى از مواد شيميايى در مغز در نظر گرفته مى شى

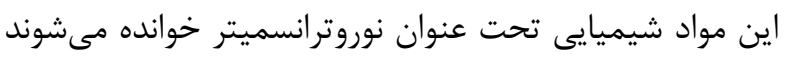
و براى عملكرد طبيعى، مغز به اين نوروترانسميترها نياز دارد.

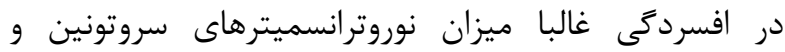
نور آدرنالين كاهش مى يابد (ع). مطالعات متعددى اثرات ضدافسردگى گياهان بومى كشورهاى جين،كره و هند را ززارش كردهاند(9 (1). در بيشتر اين كزارشها، افزايش محسوس و قابل توجه ميزان كتكول آمينها و سروتونين در سيستم عصبى مركزى گزارش شده است. از آنجايى كه آزمون شناى اجبارى باعث ايجاد تغييرات محسوسى در ميزان سروتونين يلاسماى خون مىشود (^)، هر گونه تغيير در زمان بى حركتى را در آزمون شناى اجبارى مى توان به تغييرات ميزان سروتونين در سيستم عصبى مركزى نسبت داد.

در اين مطالعه اثرات ضدافسردگى ناشى از تجويز عصاره

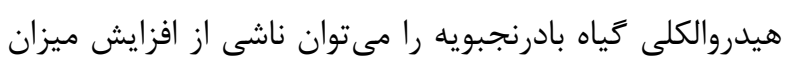
نوروترانسميتر سروتونين دانست، كه نقش مهرمى در پاتوزنز افسردگى دارد. در ارتباط با دوزهاى به كار برده شده عصاره

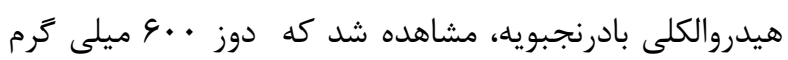
بر كيلوگرم عصاره بيشتر مانند داروى فلوكستين عمل كرده

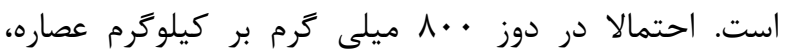

\section{REFERENCES}

1. Archer J. Tests of emotionality in rats and mice: a review Anim Behav 1973; 21:205-235.

2. Balzer DG. Mood disorders. In: Sadock BJ, Sadock VA. Editors. Kaplan \& Sadock comprehensive, Textbook of Psychiatry. $7^{\text {th }}$ ed. Philadelphia: Lippincott Williams \&Wilkins; 2000. P.1298-308.

3. Borsini F, Meli A. Is the forced swimming test a suitable model for revealing antidepressant activity? Int Clin Psychopharmacol 1998; 94:147-160. 
4. Cryan JF, Valentino RJ, Lucki l. Assessing substrates underlying the behavioral effects of antidepressants using the modified rat forced swimming test. Neurosci Biobehav Rev 2005; 29: 547-569.

5. Ghayour MB, Rasouli MB, Ghayour N, Tehranipour N, Kamyabi Abkooh A. Anticonvulsant and calming effects of aqueous-alcoholic extract of Melissa officinalis L .induced by penthylen tetrazol in rats. J Med Plants 2011; 8:64-73. [In Persian]

6. Hadipour Jahromi M, Khakpour SH, Fetroos A. Antidepressant effect of hydroalcoholic extract of Biebersteinia multifida DC in rats, Iran J Bio Sci 2007; 2:29-35. [In Persian]

7. Kaplan HI, Sadock BJ, Editors. Synopsis of psychiatry. Behavioral sciences. $7^{\text {th }}$ ed. Philadelphia: Lippincott Williams \& Wilkins; 1998. P.524-73.

8. Lynn G, Lucki L. Interaction between the forced swimming test and fluoxetine treatment on extracellular 5hydroxytryptamine and 5-hydroxyindoleacetic acid in the rat .J Pharmacol Exp Therap 1997; 282:967-976.

9. Mahmoodi M, Heidari Mr, Zohoor Ar. Experimental study to evaluate the pretreatment of Melissa Officinalis extract against lethal seizures induced by Pentylentetrazole in Wistar rats, J Kerman Uni Med Sci, 2001; 8:88-94.

10. Miladi Gorji H, Vafaee AA, Bagheri A. The study of Portulaca Oleracea L. and Melissa officinalis L. on sleep in mice. J Med plants 2011; 1-7.

11. Mohammadi MR, Davidian H, Noorbala A, Malekafzali H, Naghavi H, Pouretemad H et al. An epidemiological disorder in Iran. Clin Pract Epidemiol Ment Health 2005; 1:1-16.

12. Nutt DJ. Relationship of neurotransmitters to the symptoms of major depressive disorder. J Clin Psychatry 2008; 69:4-7.

13. Park SW, Kim YK, Lee JG, Kim SH, Kim JM, Yoon JS, et al. Antidepressant-like effects of the traditional Chinese medicine kami-shoyo-san in rats. Psychiatry Clin Neurosci 2007; 61:401-406.

14. Perry EK, Pikering AT, Wang WW, Houghton PJ, Perry NS. Medicinal plants and Alzheimer disease from entobotany to phytotherapy. J Pharm Pharmacol 1999; 51: 527-534.

15. Porsolt RD, Le Pichon, Jalfre M. Depression: a new animal model sensitive to antidepressant. Nature 1977; 266:730-732.

16. Rogers SL, Friedholf LT. Long-term efficacy and safety of donepezil in the treatment of Alzhheimer disease: an interim analysis of results of a US multicenter open-label extension study. Eur Neuropsychopharmacol 1998; 8:67-75.

17. Samsaam Shariat H, Moatar F, Editors. Treatment by plants. Tehran, Iran: Mashal Publication; 1987. P.155-203.

18. Steru L, Chermat R, Thierry B, Simon P. The tail suspension test: a new model for screening antidepressants in mice. Psychopharmacology 1985; 5:367-70.

19. Yu ZF, Kong LD. Antidepressant activity aqueous extracts of Curcuma longa in mice. J Enthopharmacol 2002; 83:161-16.

20. Zargari A, Editor. Medicinal plants. Tehran: Tehran University Publication; 1992. P.77-82. 